\title{
Chinese Macroliquidity System and Comprehensive Liquidity Index
}

\author{
Wenhao Lai ${ }^{1, *}$ \\ ${ }^{1}$ Ningbo Xiaoshi International center IB, 155 Shubo Road, Yinzhou District, Ningbo City, Zhejiang Province, China \\ *Corresponding author. Email: johnsonlwh2003@163.com
}

\begin{abstract}
Macroliquidity means the amount of money in the economy which allows the markets function efficiently. It not only reflects the financing difficulty of the enterprise, but also the amount of the supply and demand for funds. In general, it is a pretty important variable to reflect the economic macroscopic environment. Therefore, it is necessary to construct an easy-tracking indicator to reflect the macroliquidity of the whole country. As we all know, until now, there is not a widely recognized and applied index in China to reflect macro liquidity. Most investors or policy makers mainly observe the macroliquidity by detecting and tracking a single index, such as aggregate financing to the real economy, Shanghai Offered Rate (Shibor) and so on. However, tracking just one index is not always reliable or comprehensive. We are pretty curious about whether an overall index could be invented to reflect the macroliquidity as a whole. In order to investigate this topic, to begin with, we understand the process about how the liquidity is generated in China, then we collect different indicators that reflect the liquidity for each stage. The next step is to combine and synthesize these indicators together hierarchically, and finally we construct an index that reflects the macroliquidity in China.
\end{abstract}

Keywords: Macroliquidity, liquidity index, economic index, monetary policy, standardization, quantile normalization method

\section{INTRODUCTION}

In this contemporary era, with the rapid development of the society, it is common to see a lot of transactions or trades happened among the world. In other words, the transfer of money occurs anytime anywhere. However, to make sure the economy is able to operate in an efficient way, there should have enough money to put into the economy, which is also called macroliquidity $[1,2,3]$. In this paper, we will mainly focus on the macroliquidity in China. To start with, what is macroliquidity? Macroliquidity reflects the amount of money in the current economic system and the cost and difficulty of investment and financing activities conducted by financial institutions, enterprises and individuals. Therefore, macroliquidity plays a very important role in economy. That is also the reason why a lot of people assert that macroliquidity is equivalent to the blood of the whole financial system, is a highly concerned issue of major research institutions and analysts. To make sure these economic activities are able to operate correctly, inventing an overall index to reflect the level of macroliquidity is pretty significant. For instance, when the macroliquidity is good enough, it is much easier for people to borrow some money they want. Moreover, the interest rate will also decrease, leading to more investment and more consumption. As a result, the aggregate demand will also increase, which means the real GDP will also increase. However, if the macroliquidity does not reach the expected value, people are unlikely to borrow enough money they want the consumption or investment will also decrease, which reduces the real GDP.

In order to find out the level of macroliquidity, people always detect and observe different indexes. However, currently, in China, there is not a widely applied and official index to directly show the macroliquidity. Under this situation, most investors or policy makers always observe and track just single index, like aggregate financing[4] to the real economy and so on. Although these indexes are able to give people some insights about the current liquidity, they are not very comprehensive or always reliable.

Due to the lack of comprehensive index to reflect the level of macroliquidity, it is pretty imperative to investigate this overall index to benefit the whole society and people. So, we design such an index by considering several different indexes inside the macroliquidity. In general, the formation of macroliquidity in China can mainly divided into two steps, which is also called secondary banking 
system. For the first step, the central bank produces the monetary bases[5], which can be regarded as the most basic requirement for liquidity of money to happen. Then, these monetary bases are expended between the central bank and different commercial banks. For the second step, the commercial banks will derive the money by absorbing the deposit and issuing the loans. To observe the macroliquidity situation in China, we can not only look through the perspective of quantity according to money supply, amount of deposit and loan and aggregate financing to the real economy, but also through the perspective of interest rate like interbank market interest rates and the saving or borrowing rates. We collect and process the indexes from these two perspectives. We mainly employ two standardization methods including mean-variance normalization and quantile normalization to preprocess these indexed, and construct our China macroliquidity comprehensive index by weighted average.

\section{THE PRODUCTION OF THE LIQUIDITY}

In general, the liquidity can mainly be divided into three categories. The first category can be called the macroliquidity. Macroliquidity indicates the amount of money created by the central bank in the overall economy. The second category is the interbank market liquidity, which mainly indicates the disposable monetary funds in the banking system. In other words, the interbank market liquidity also reveals the liquidity in monetary market. For the third category, namely the stock market liquidity, it always reflects the amount of money in the stock market. In this research paper, we will mainly focus on the macroliquidity in China.

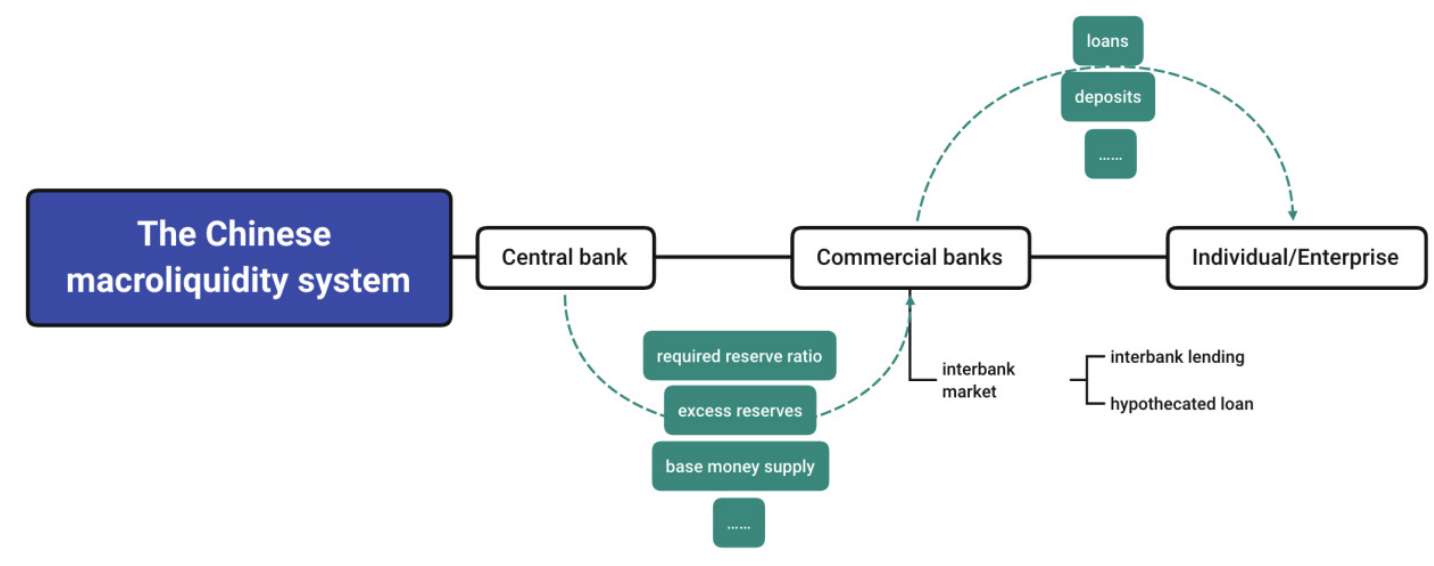

Figure 1 The process about the production of liquidity in China

The Chinese macroliquidity system mainly constitutes three characters: the central bank, commercial banks, individuals or enterprises. The process about the production of the liquidity comprises two steps. The central bank will create the monetary base to the commercial banks. Then, the commercial banks will expand the derivation of money through the investment or financing by the enterprises or individuals. In addition, the commercial banks will also manage the liquidity through the interbank market.

Specifically, firstly, the central bank and other functional departments supply monetary base to commercial banks through open market operations and other means. The amount of monetary base could be revealed by the central bank balance sheet, money supply and the open market operations. The balance sheet will directly reflect the stock and increment of base money. And money supply[6] is used to see the changes of the amount of base money being produced, which mainly includes three aspects $M \_0, M \_1, M \_2$. In addition, in order to control the amount of money supply being offered by the central bank, the market operation is used, including open market reverse repos, state treasury cash fixed standing lending facilities, mortgage supplement loan and so on. This part is the first step for the macroliquidity to form.

Secondly, commercial banks expand the base money through credit business and get derived money. When the commercial banks borrow the money from the central bank, they need to reserve in excess of the reserve requirement set by a central bank, called excess reserved[7]. In other words, the proportion of the deposits that cannot be borrowed in the commercial banks is fixed, which is the also called the reverse ratio. The second step talks about the liquidity forms between the central bank and the commercial banks by borrowing money. Moreover, among different commercial banks, they always borrow some money from other companies to satisfy their current need. The interest rate of borrowing is called the interbank market interest rates. It includes interbank lending rate, repo rate, interest rate swap and so on. In general, it mainly depicts the inter-bank liquidity cost. 
Finally, some micro enterprises and individuals do some financing activities to form liquidity. And they can further circulate liquidity in the real economy through investment, private lending and other ways. This step mainly includes two aspects: the loans from commercial banks to the enterprises or individuals and the deposit from the enterprises or individuals to the commercial banks. By borrowing or saving money from the individuals and enterprises, the macroliquidity is also being further produced. Through the scale of social financing, loan price and rate of return on investment these three aspects, the liquidity for the third part can be estimated. The scale of social financing refers to the total amount of funds that the real economy receives from the financial system in a

certain period, reflecting the changes in the liquidity support that the real economy receives. The loan price includes two parts, namely the size of the loan and the loan interest rate. In addition, the change of rate of return on investment reflects the change of risk preference and risk premium, and reflects the degree of looseness of liquidity from the side.

These three steps above generate the macroliquidity in China together.

\section{THE ECONOMIC INDEXES REFLECT LIQUIDITY}

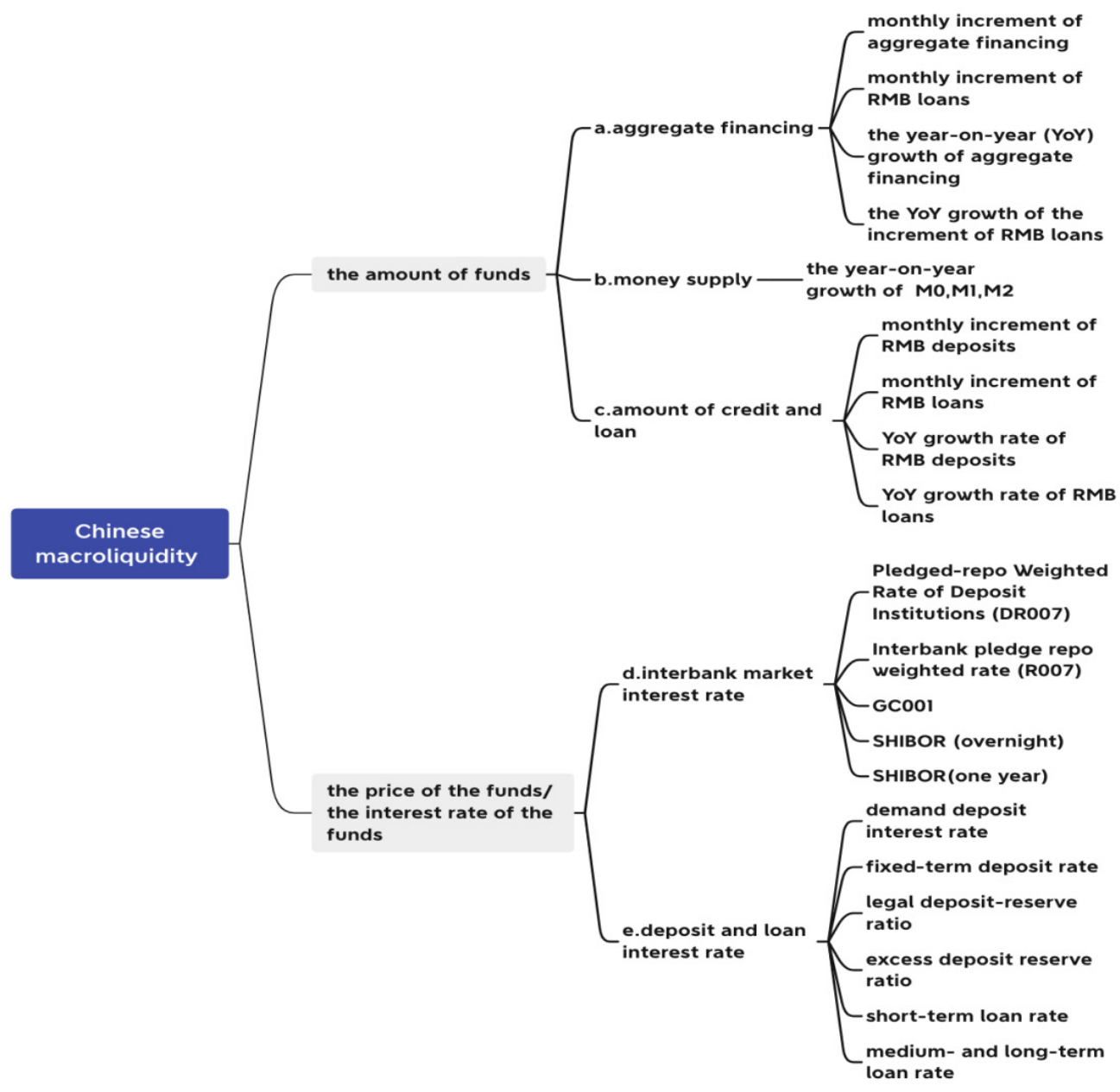

Figure 2 The economic indexes reflect liquidity

In order to observe the macroliquidity, we mainly look through two perspectives, the amount of funds and the interest rate of the funds. From the perspective of the amount of funds, it mainly includes three aspects, the aggregate financing, money supply and the amount of credit and loan. In general, the more the amount of funds, the better the macroliquidity is.

\section{a. Aggregate financing}

The aggregate financing means, in a certain period, the amount of funds getting from the financial system for the whole real economy. In other words, it reflects the changes in the liquidity support that the real economy receives. It mainly reflects the second part of the production of macroliquidity. In order to detect the level of aggregate financing, we always observe four indexes, including monthly increment of aggregate financing, monthly 
increment of RMB loans, the year-on-year (YoY) growth of aggregate financing and RMB loans.

\section{b. Money supply}

Money supply is used to see the amount of monetary base being produced by the central bank. To observe the level of money supply, we always observe the year-on-year growth of M0, M1, M2. M_0 always indicates the amount of cash being circulated in the economy, which also shows the wealthy level of people. M_loften illustrates the purchasing power of the society. As for M_2, it not only includes the amount of cash being circulated in the economy and the unit current deposit that can be paid by writing a check, but also the household savings deposit, time deposit of the company, other deposits of the company and the margin of clients of the securities company. By using M_2, it can reflect both the current purchasing power and the potential purchasing power.

\section{c. Amount of deposit and loan}

The amount of deposit means the sum of all saving, such as demand deposits, time deposits, settlement accounts and margin deposits. In other words, it is the total amount of money people keep in banks. The amount of loans is the sum of the loans of various banks. The increase or decrease of the amount of deposit and loans are able to reflect the development of the economy. In order to detect the amount of deposit and loan in the economy, four main indexes are always used: monthly increment of RMB deposit and loans and the YoY growth rate of RMB deposits and loans. In general, the amount of deposit and loan reflect the second step during the production of the macroliquidity.

From the perspective of the interest rate of the funds (or the price of the funds), it mainly includes two aspects, interbank market interest rate and the interest rate of loan and deposit. As for the interest rate, the lower the interest rate, the better the macroliquidity is.

\section{d. Interbank market interest rate}

The inter-bank market interest rate means when a bank borrows some money from another bank, the bank who borrows the money need to return the money plus the interest rate. The interbank market interest rates, including: interbank lending rate[8], repo rate[9], interest rate swap and so on, can be indirectly reflected in the marginal cost of a single bank's expansion of the derived currency without increasing the total inter-bank base money, that is, it depicts the inter-bank liquidity cost. In general, this index mainly reflects the liquidity between the banks. To observe the value of the interbank market interest rate, we always look through Pledged-repo Weighted Rate of Deposit Institutions (DR007), Interbank pledge repo weighted rate (R007), GC001, SHIBOR[10] (overnight and one year).

\section{e. The interest rate of loan and deposit}

The interest rate of loan and deposit means the interest rate when people save money into the commercial banks or make loans from the commercial banks. It also reflects the second step of the production of the macroliquidity. We mainly observe six indexes to find the value of interest rate of loan and deposit in China, including demand deposit interest rate, fixed-term deposit rate, legal deposit-reserve ratio, excess deposit reserve ratio, short-term loan rate, medium- and long-term loan rate.

The data of above-mentioned indexes come from the database of Wind (https://www.wind.com.cn)

\section{CHINA MACROLIQUIDITY COMPREHENSIVE INDEX}

We hope we are able to create a comprehensive index to reflect the situation of macroliquidity in China based on different indexes mentioned above. In order to do that, the statistical methods we mainly used is the weighted average method. Then, we are able to combine and synthesize these indexes from the lower level to the higher level to help us get the overall index.

Specifically, to start with, for aggregate financing, money supply, amount of credit and loan, interbank market interest rate and deposit and loan interest rate these five main categories, we utilize the weighted mean method to get five indexes that indicate the level of liquidity for these five categories. After that, as for the amount of funds, we are able to get the overall index to reflect the quantity by combining aggregate financing, money supply, amount of credit and loan these three indexes with equal weights. Considering the interest rate of the funds, we are also able to synthesize the two indexes (interbank market interest rate, the deposit and loan interest rate) with equal weights to get an overall index that shows the price of the funds. Finally, by integrating the index that reflect the amount of funds and the index that indicate the price of funds, the China macroliquidity comprehensive index is calculated.

Since each basic index has different units and the order of magnitudes, these indexes are not comparable with each other. In order to solve this problem, we preprocess these indexes by standardization. In this research, we mainly use two standardization methods, including the mean-variance normalization and the quantile normalization. To be more specific, mean-variance normalization means use the latest observed value minus the average value of the last five years (or 60 months), then divided by the standard deviation of last five years. Quantile normalization means using the current observed value to calculate the percentage of the value that is below the current value over the past five years.

For the negative indicators, we change it into the positive indicators by adding the negative signs. By using these two standardization methods respectively, we follow the means mentioned above to construct the China macroliquidity comprehensive indexes. Finally, we get two China macroliquidity comprehensive indexes by using two different standardization methods, including the China macroliquidity comprehensive index (mean-variance normalization) and the China macroliquidity comprehensive index (quantile normalization). 


\section{RESULTS}

\subsection{The liquidity indexes of the five basic categories}

The liquidity indexes of the five basic categories are shown in the Figure 3-7. The trend of result produced by the two methods are almost the same, the correlations between mean-variance and quantile normalization are listed in Table 1. We can see the correlation in all categories are almost higher than $90 \%$.

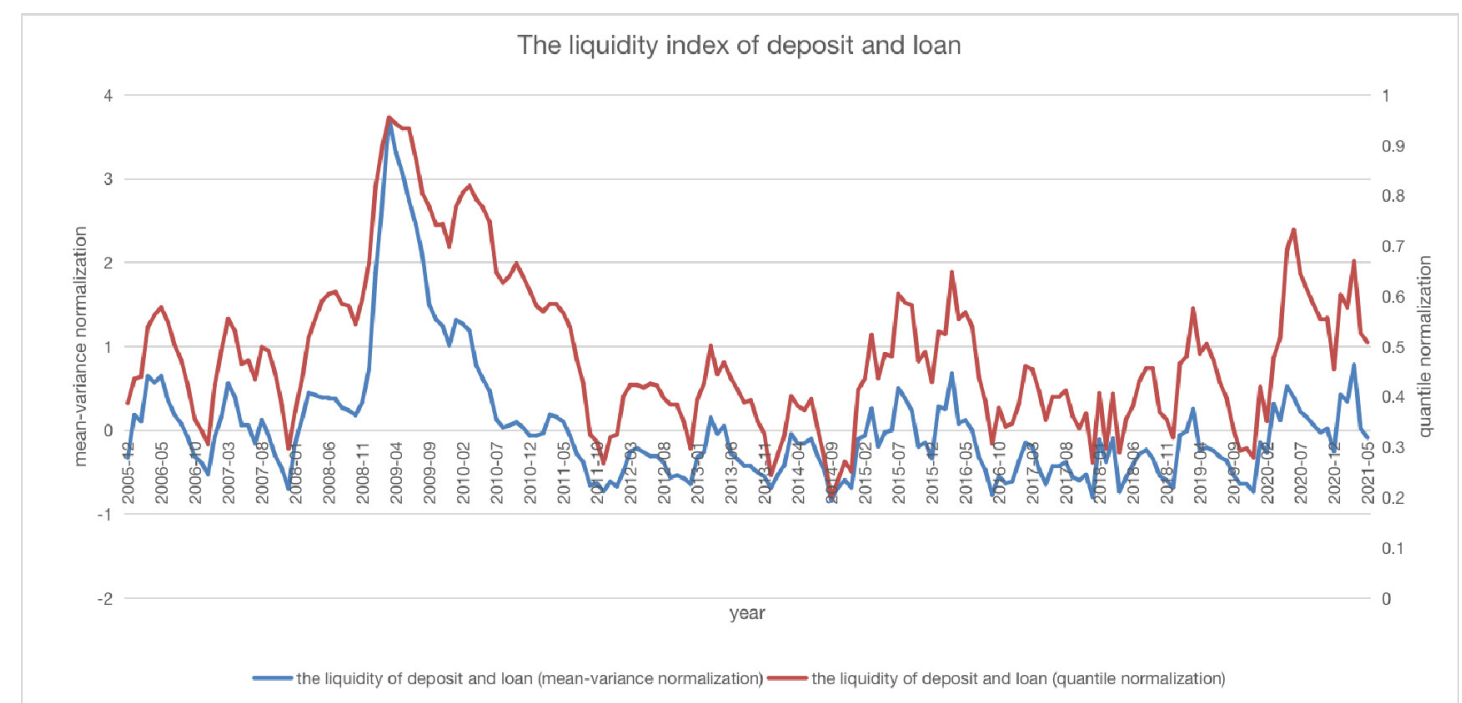

Figure 3 The liquidity index of deposit and loan

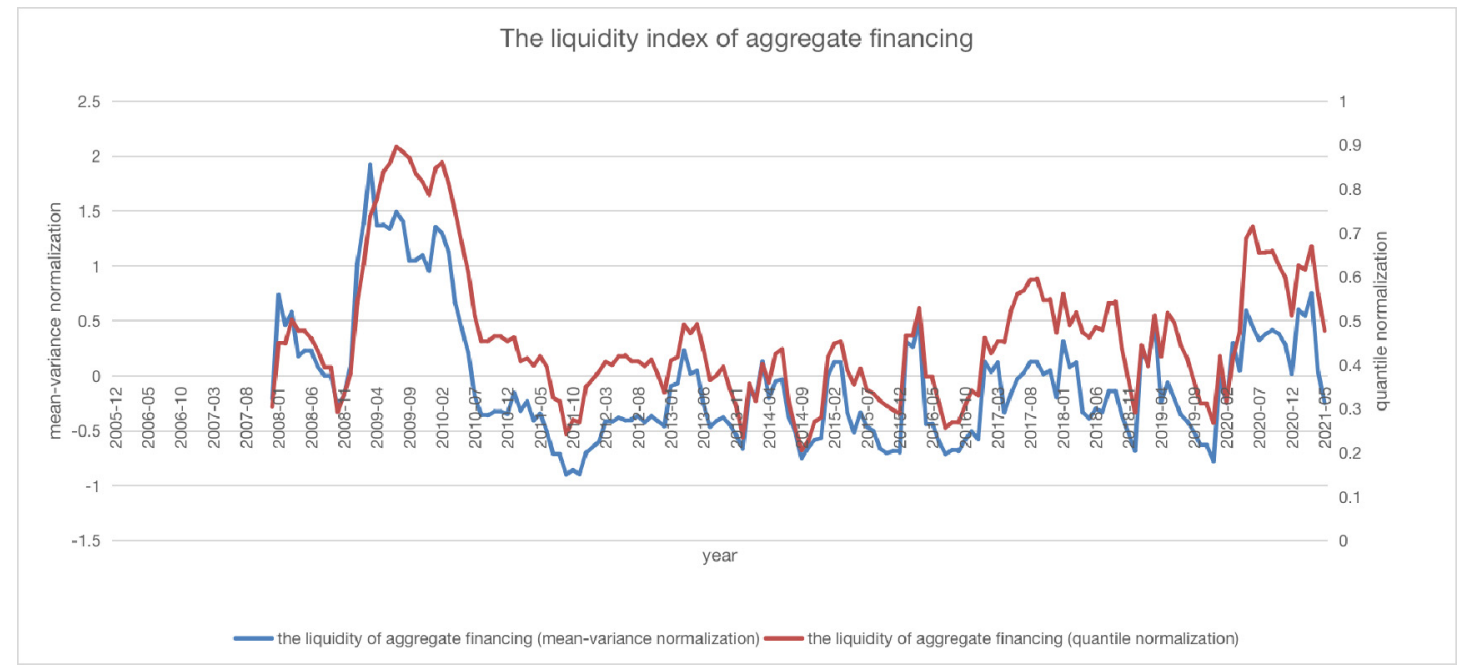

Figure 4 The liquidity index of aggregate financing 


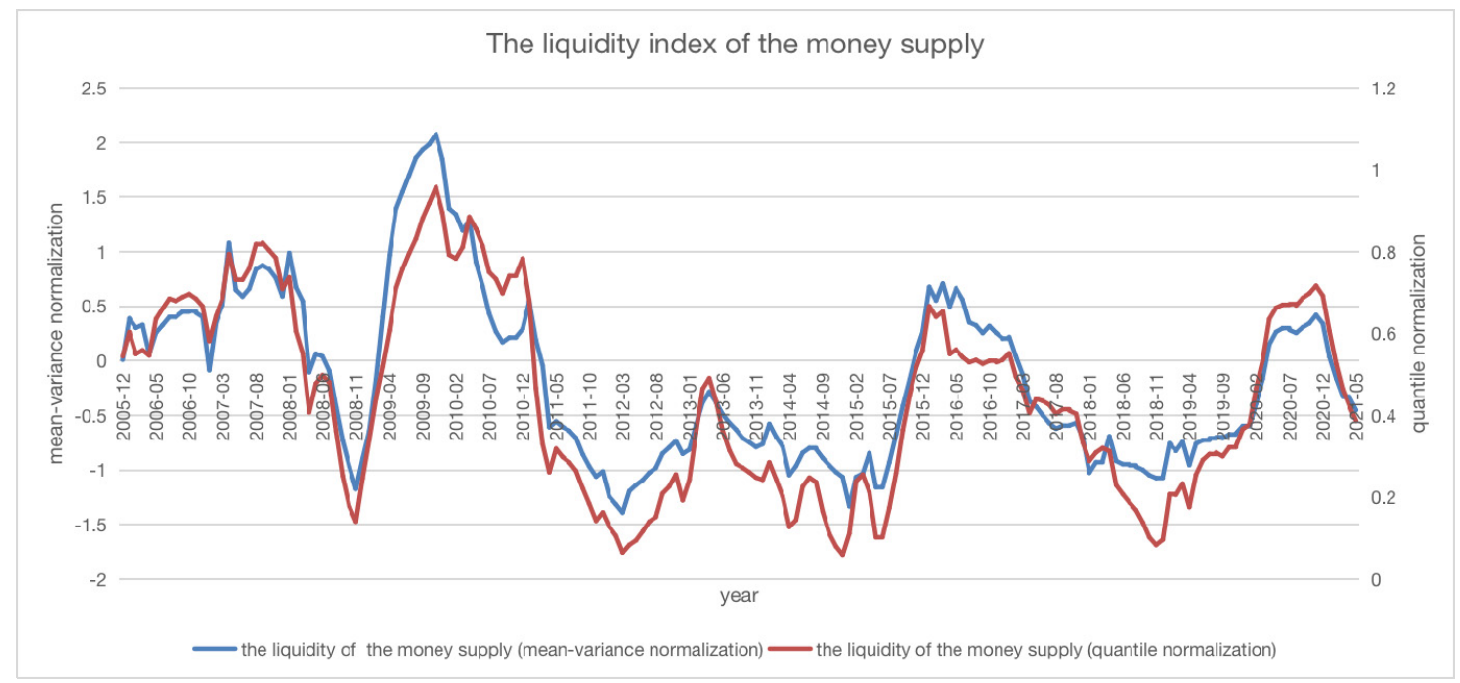

Figure 5 The liquidity index of the money supply

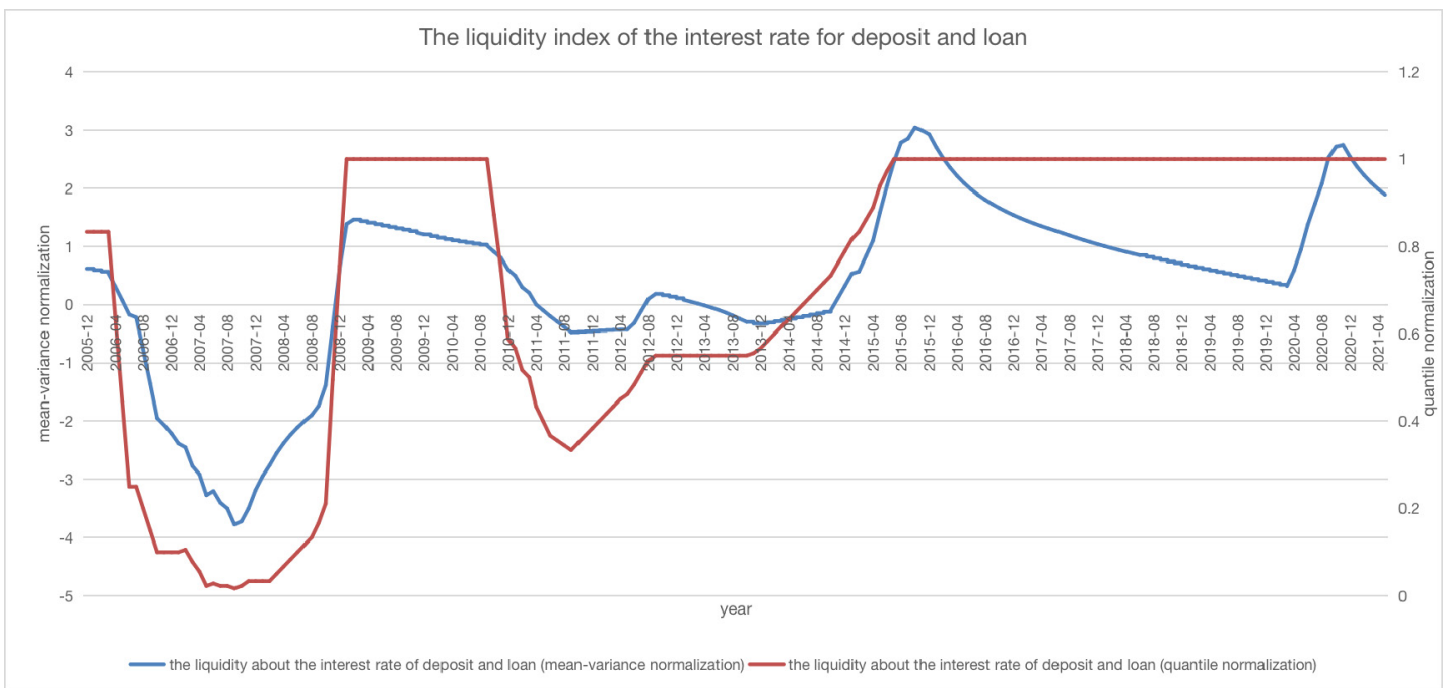

Figure 6 The liquidity index of the interest rate for deposit and loan

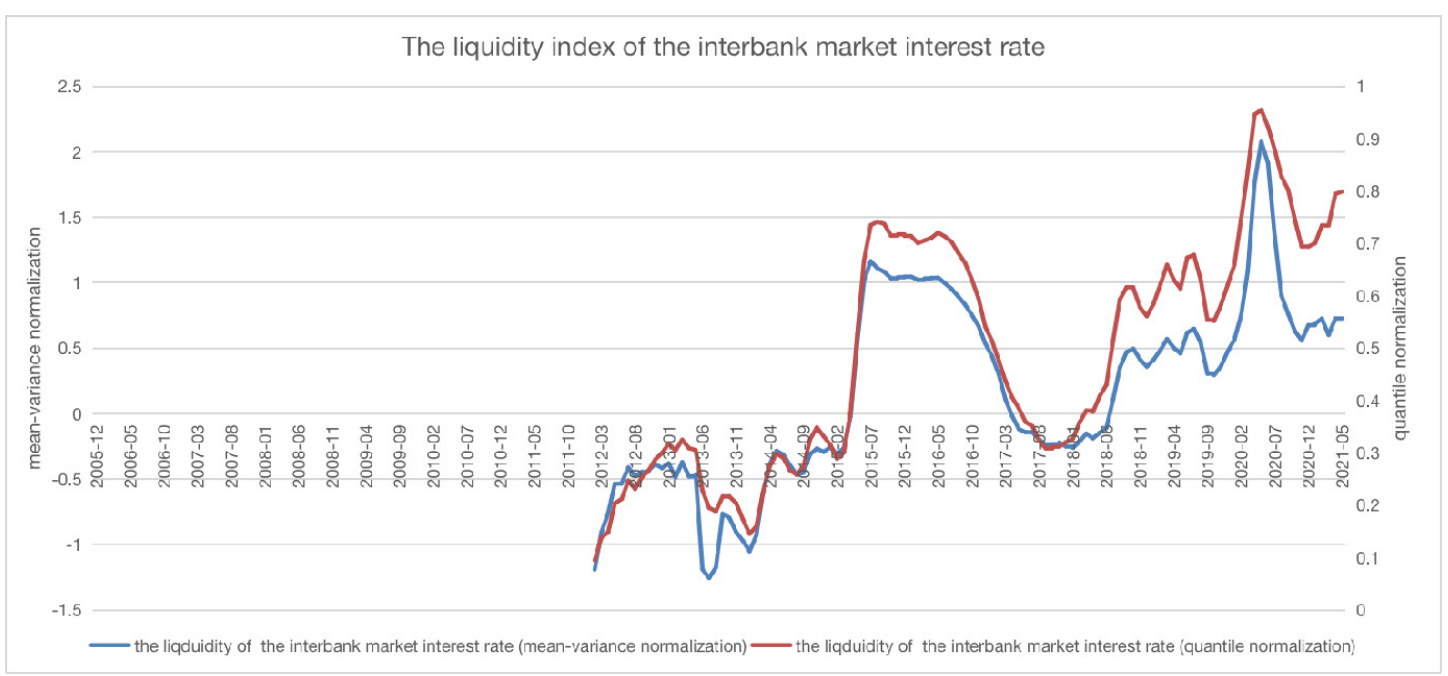

Figure 7 The liquidity index of the interbank market interest rate

From these five indexes shown in Figure 3-7, the big changes of the macroliquidity mainly happened within three time periods. The biggest change during the interval happens during the global economic crisis in 2008. Under this kind of situation, all the countries in the world exist the negative economic growth, which means the economy did 
not grow but retreat at that time. A lot of enterprises collapse and the liquidity in the economy decreases a lot. To face and overcome these difficulties, the government invest a lot of money and expand the macroliquidity. Moreover, in 2015, from the graphs above, we can see that some fluctuations happened. From Figure 3, we can find that the deposit and the loan increases at that time, which indicates that more and more people began to save or borrow more money from the commercial banks. That is the reason why the indexes are higher than other time period. In addition, recently, the covid-19 spread quickly around the world in 2020, the whole economy of the world has been affected strongly. During this time period, the economy almost stagnated without much economic activities. For the Chinese government, in order to overcome this difficult time period, they increase the macroliquidity to face the pressure from the bad economic situation.

Table 1 The correlation coefficient between mean-variance and quantile normalization

\begin{tabular}{|l|r|}
\hline & The correlation coefficient \\
\hline The liquidity of the deposit and loan & $90.3 \%$ \\
\hline The liquidity of the aggregate financing & $89.2 \%$ \\
\hline The liquidity of the money supply & $94.4 \%$ \\
\hline The liquidity of the interest rate for deposit and loan & $90.2 \%$ \\
\hline The liquidity of the interbank market interest rate & $96.7 \%$ \\
\hline
\end{tabular}

\subsection{The quantity/price comprehensive macroliquidity index}

The quantity and price comprehensive macroliquidity indexed calculated with mean-variance normalization method are shown in Figure 8, while the results with quantile normalization method are shown in Figure 9.

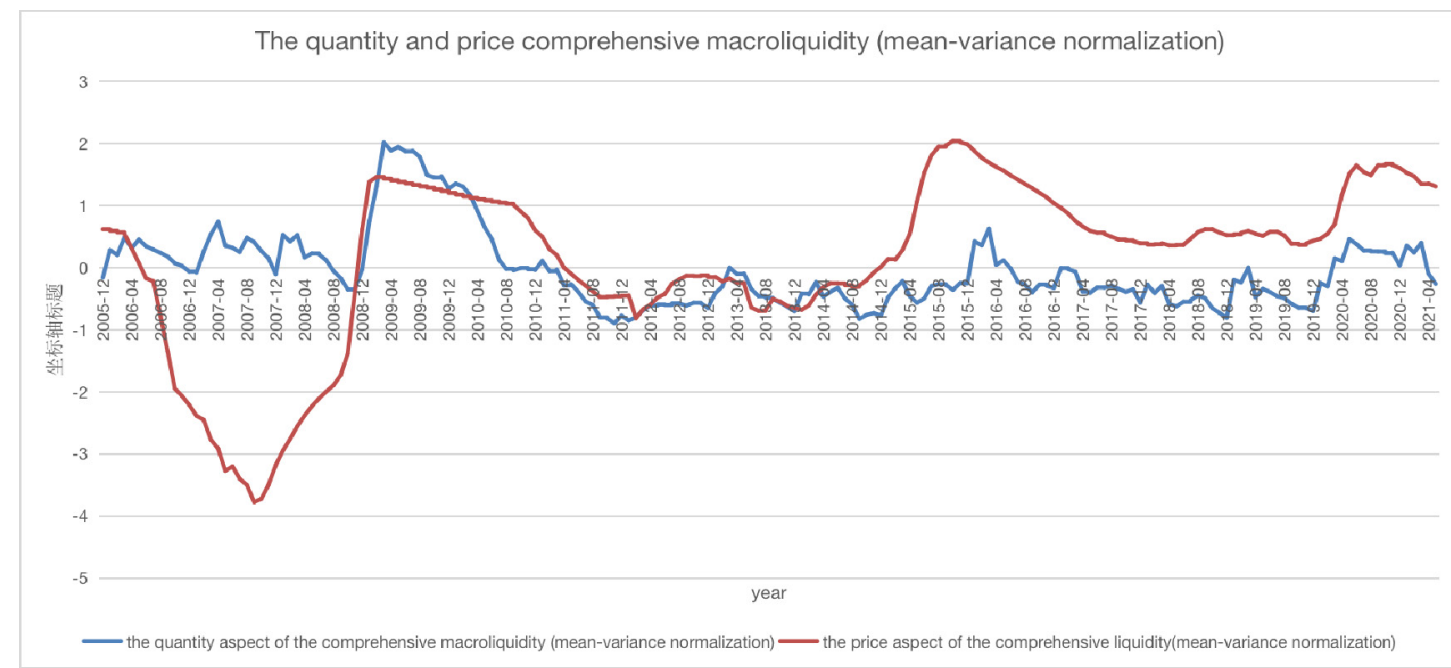

Figure 8 The quantity and price comprehensive macroliquidity index with mean-variance normalization method

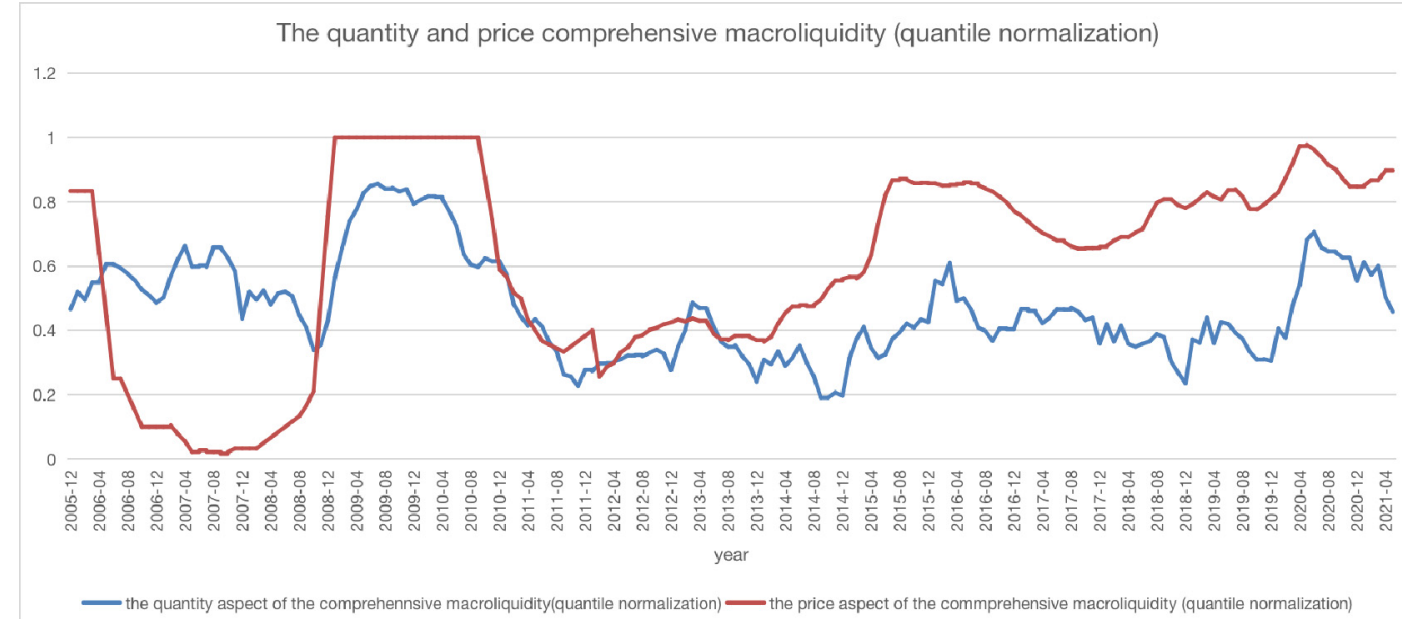

Figure 9 The quantity and price comprehensive macroliquidity index with quantile normalization method 
Similarly, the correlations of indexes with two different standardization methods are $92.8 \%$ and $92.7 \%$ for price and quantity respectively, and the trend of them are the same. As we can see in Figure 8-9, in 2007 and 2014, the price comprehensive macroliquidity will increase first, then the quantity comprehensive macroliquidity will increase afterward. The followed increment of quantity comprehensive macroliquidity followed by the increment of price comprehensive macroliquidity shows that governments will firstly adjust the interest rate. When the interest rate is adjusted be lower than before, the amount of funds will increase, which will promote the growth of the economy. This phenomenon also indicates that China always adjusts the interest rate to manage the liquidity situation.

\subsection{The China macroliquidity comprehensive index}

The China macroliquidity comprehensive index is shown in Figure 10. The correlation of the two indexes calculated by mean-variance normalization and quantile normalization is $93.3 \%$, and the trend of them is almost the same.

From 2005, the Chinese macroliquidity mainly experiences three cycles. The first cycle happens in 2008, the big economic crisis happened not only in China but the whole world. The second cycle happen in 2015. Within this time period, much more people began to deposit or make loans from the commercial banks. Moreover, recently in 2020 , the extreme infectious virus called the covid-19 virus spread quickly in China, which cause a lot of factories stop working and the transactions or the transfer of money also decreases a lot. In order to face and overcome these crisis, government will always increase the macroliquidity by adjusting the level of aggregate financing, money supply, amount of deposit and loan, the interest rate of deposit and loan as well as the interbank market interest rate.

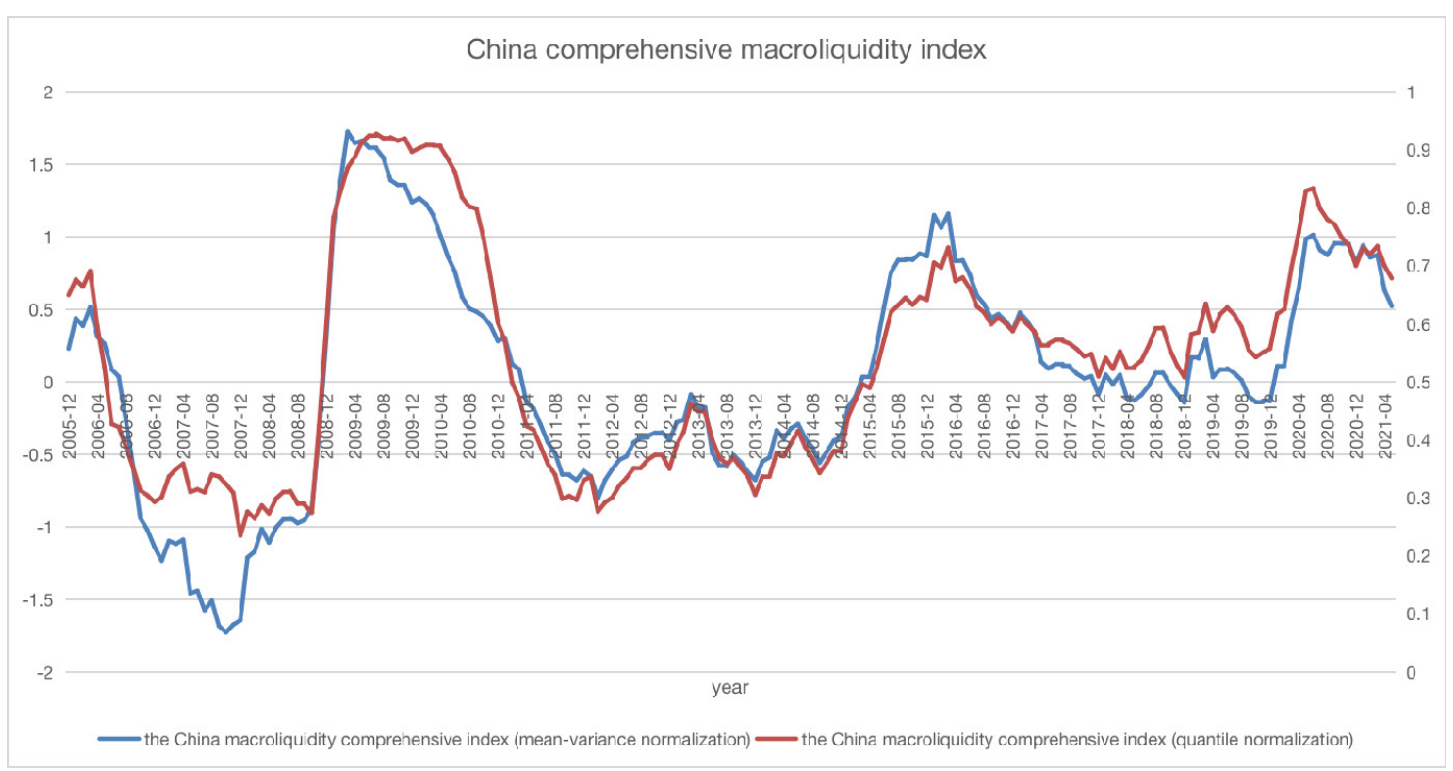

Figure 10 The China macroliquidity comprehensive index

\section{CONCLUSIONS}

In this research paper, we mainly focus on designing a comprehensive index to reflect the macroliquidity level in China. The investigation of this comprehensive index will benefit the investors or policy makers to observe the macroliquidity more accurately so that they will be able to make accurate decisions.

In order to investigate this topic in depth, we firstly understand the process about the production of the macroliquidity in China through the secondary banking market. In addition, we also collect different easy-tracking indexes that reflect each stage in the process. Then, we construct the China comprehensive macroliquidity index based on these indexes by using two standardization methods and weighted average. To sum up, the indexes produced by these two standardization methods are pretty close. Based on the China comprehensive macroliquidity indexes, we can obviously observe that the macroliquidity of China experienced mainly three cycles, including the 2008 economic crisis, 2015 finance bubble and 2020 covid-19 virus.

The creation of the China comprehensive macroliquidity index is helpful for people to understand the situation of macroliquidity. By understanding the level of macroliquidity, we can also try to find out the events happened at different time, which causes the different level of macroliquidity in China.

\section{REFERENCES}

[1] Nguyen C P , Schinckus C , Su T D, et al. Determinants of stock market returns in emerging markets: The linkage between institutional quality and macro liquidity[J]. International Journal of Finance \& Economics, 2020. 
[2] Chris, Florackis, Alexandros, et al. Stock market liquidity and macro-liquidity shocks: Evidence from the 2007-2009 financial crisis[J]. Journal of International Money and Finance, 2014, 44(1):97117.

[3] Shi C X , Ferdousi F , Wang Q H . A Study of Macro Liquidity Imbalance Reversal—Based on Markov Mechanisms Conversion Model[J]. Journal of Taiyuan University of Technology(Social Sciences Edition), 2013.

[4] Guo L, Zhang X, Xu L. Research on the Effect of Aggregate Financing and Financial Structure on the Real Economy[J]. Studies of International Finance, 2014.

[5]I Costică. Financial Crisis And Changes In The Monetary Base[J]. Theoretical and Applied Economics, 2009, 12(541)(supplement)(3):277-285.

[6]Asymmetric Effects of Positive and Negative Money-Supply Shocks[J]. Social Science Electronic Publishing, 2007, 107(4):1261-1282.

[7] Fang Y . The Development of Chinese Payment System and The Fluctuation of Excess Reserve Demand[J]. Shanghai Finance, 2008.

[8] Cheng K C . A VAR Analysis of Kenya's Monetary Policy Transmission Mechanism; How Does the Central Bank's REPO Rate Affect the Economy?[J]. Imf Working Papers, 2006, 06(300).

[9] Brighi P . Interbank Lending, Liquidity and Banking Crises[J]. Economic Notes, 2002, 31(3):493-521.

[10] Guo J , Director, Division I P , et al. Shibor and interest rate marketization[J]. China Money, 2007. 